\title{
Türkiye'nin Kalkınmasında Bir Adım Olarak Teknoparkların Etkin İşleyişi
}

Sabahattin Tuğrul IMER (https://orcid.org/0000-0003-1596-3048), Gazi Teknopark, Gazi University, Turkey; email: tugrul@crworldinc.com

Mustafa Kemal ÖKTEM (https://orcid.org/0000-0002-2040-426X), Department of Political Science \& Public Administration, Hacettepe University, Turkey; e-mail: kemalok@ hacettepe.edu.tr

Osman Tolga KASKATI (https://orcid.org/0000-0001-8299-2397), BYS Grup Bilişim Sistemleri, Gazi

Teknopark, Gazi University, Turkey; e-mail: tolga.kaskati@bysproje.com

\section{Efficiently Operating Technoparks: A Step Towards Turkey's Development}

\begin{abstract}
Technoparks are economic public policy tools. Their success depends on government-backed support mechanisms, incentives and legislation, and the services and programs provided by the management companies. Today in Turkey, it might not be easy to measure the effectiveness of technoparks in nation's growth and development since there are too many parameters involved. This article elaborates on the effectiveness of technoparks in generating the desired benefits within the framework of the current technology and innovation policies and the potentials of the resident companies. The hypothesis is that, despite the involvement of complex public management aspects, the capacity and the potential of the technopark companies appear as the most critical parameters. Nevertheless, the performance of the companies will determine the value that the technoparks shall add to economic growth and development.
\end{abstract}

Keywords

Technopark, Innovation, Industry, Technology, Economic Development, Economic Growth, Public Policy, R\&D, Value Added.

JEL Classification Codes: $\quad$ O3, O31, O32, O33, O38, M14, M13.

\section{$\ddot{\mathbf{O} z}$}

Ekonomik kamu politikası modelleri olarak teknoparkların başarısı bir yandan kamu politikalarıyla sağlanan teşvik, destek ve mevzuata, bir yandan da teknopark yönetimlerinin uyguladıkları faaliyetler ve düzenledikleri programlarla doğrudan ilintilidir. Bugün Türkiye' de teknoparkların büyüme ve kalkınmadaki etkinliklerini ölçmek kolay olmayabilir çünkü doğrudan ve dolaylı etkiler ile bununla ilintili parametrelerin sayısı çoktur. Bu makalenin amacı Türkiye'deki teknoparkların bu anlamdaki etkinliklerini mevcut teknoloji ve inovasyon politikaları, teknopark şirketlerinin faaliyetleri ve firma potansiyelleri çerçevesinde ortaya koymak ve bunları artırmaya yönelik genel odak noktalarını tartışmaktır. Burada, kamu yönetiminin karmaşık-boyutları olsa da nesnel-değişken olarak en önemli etkenin teknoparktaki şirketlerin kapasite ve potansiyeli olduğu hipotezi vurgulanmaktadır. Çünkü şirketlerin çıktısı teknoparkların sağladığı faydanın çıktısı olarak ekonomi ve kalkınmaya yansıyacaktır.

Anahtar Sözcükler $\quad$ : Teknopark, İnovasyon, Sanayi, Teknoloji, Kalkınma, Kamu Politikası, Ekonomik Büyüme, AR-GE, Katma Değer. 
İmer, S.T. \& M.K. Öktem \& O.T. Kaskatı (2021), “Türkiye'nin Kalkınmasında

Bir Adım Olarak Teknoparkların Etkin İșleyiși”, Sosyoekonomi, 29(48), 407-426.

\section{Giriş}

Tanımsal anlamda teknoparklar ABD Kaliforniya Silikon Vadisi'nde 1951 yılında kurulmuş olan "Stanford Research Park" ile ortaya çıkmış ve günümüze kadar bilim park1, bilim kenti, teknoloji kenti, teknoloji geliştirme bölgesi, vb. gibi çeşitli isimler almıştır. Teknoparklar günümüzde kavramsal olarak bilim ve teknoloji tabanlı endüstriler kategorisinde faaliyet gösteren ve bununla birlikte araştırma geliştirme (AR-GE)'ye dayalı ürün ve hizmet geliştirerek bunlardan gelir elde etmeyi hedefleyen firmaların bir arada bulunduğu platform ya da organizasyonlar olarak tanımlanabilir.

Makro düzeyli bir bakış açısı ile teknoparklar bulundukları bölgenin ve ülkenin iktisadi büyüme ve kalkınmasında kullanılan kamu politikası araçları olabilirler. Bu anlamda ana hedef olarak teknoparkların büyümeye ve kalkınmaya katkıları, bir yandan istihdamı arttırmak, bir yandan da AR-GE faaliyetleri sonucu ortaya çıkacak yüksek katma değerli ürünlerin pazara giriş hacmini yükseltip ekonomiye daha fazla gelir-girdisi kazandırmaktır. Böylelikle hem büyümeyi hem de üretkenliği arttırmak, aynı zamanda da başka bilimsel ve teknolojik gelişmelere olanak sağlamak olanaklıdır.

Bu bağlamda, büyüme ve kalkınma ile ilgili hedeflere ulaşmak için teknoparklar tarafından ortaya konulacak katkılar aslında orada konuşlanmış şirketler tarafından üretilen çıktılar nispetinde olacaktır. Dolaysıyla şirketler ne kadar başarılı ise teknoparklar da o düzeyde katkıyı arttıracak, ülke ekonomisine de o oranda faydalı olacaklardır.

Aslında teknopark konsepti ile bir küme mantığı çerçevesinde aynı yerde konuşlanmış farklı şirketlerin birbirileri ve teknoparkın ilintili olduğu, başta üniversite olmak üzere, birçok işbirliği kuruluşu ile etkileşim içinde olması, bu sayede teknoloji transferinin sağlanması ve AR-GE kültürünün oluşmasıyla, firmaların imkân, kabiliyet, kapasite ve motivasyonlarının arttırılması düşünülmüştür. "Teknoloji transferi” konusu, çok-disiplinli bir inceleme, sentez ve eleştirel bakış gerektirebilir. Üniversiteler ve kamu laboratuvarlarından iç-teknoloji transferi de ayrı bir başlık olabilir. Temel kavramsal konular belirsizlik de içermektedir. Teknoloji transferi üzerine literatürü analiz etmede bir çözüm olarak, örneğin Bozeman (2000), "Teknoloji Transferi Durumsal Etkililik Modeli" (Contingent Effectiveness Model of Technology Transfer) oluşturmaya çalışmıştır. Araştırmaları ve kuramı etkileyen teknoloji transfer kavramları, teknoloji etkililiğinin çeşitli biçimlerde olabileceğini varsaymaktadır. Piyasa etkilerinden kaynaklı geleneksel etkililik ölçütleri yanı sıra, siyasal etkililik ve kapasite-geliştirme gibi farklı seçenekleri dikkate alan model geliştirmenin yararlı olacağ 1 görülmektedir. Bu modele bir uyarlama daha eklenerek, "kamu değeri (public value) önemli olarak vurgulanmıştır (Bozeman et al., 2015: 36-38): Teknoloji transferi değişkenleri; niş teknoloji olması, misyon, sektör, kaynaklar, coğrafi konum, bilimsel ve teknik insan sermayesi, kurumsal tasartm, siyasal kusitlar olabilir. Transfer yöntemleri; açık kaynaklar, patent, telif, lisans, özümseme, gayri-resmi, personel takası, yerinde ziyaret, başlatıcı yatırım gibi sıralanmaktadır. Transfer konusu; bilimsel bilgi, fiziksel teknoloji, teknoloji tasarımı, süreç, uzmanlık (know-how), ustalık (craft) olabilir. Talep ortamını; transfer nesnesine mevcut talep, potansiyel indirgenmiş talep, transfer nesnesinin ekonomik niteliği etkileyebilir. Transferin alıcısı, bilimsel ve teknik insan 
sermayesi, kaynaklar, imalat deneyimi, pazarlama yetenekleri, coğrafi konum, çeşitlilik, işletme stratejileri olabilir. Transfer nesnesinin kullanımının etkililiğini; firsat maliyeti, bilimsel ve teknik insan sermayesi, siyaset, ekonomik kalkınma, kamu değeri, piyasa etkisi, kapıya kadar geçirilmesi etkileyebilir. Her bir değişkenin kuramsal temeli yanı sıra olumlu ve olumsuz yönleri belirtilmektedir, örneğin, Kamu Değeri, teknoloji transferinde toplumsal iyi ve geniş anlamda paylaşılan değerleri geliştirmekte midir sorusu, kamu yararı kuramına dayalıdır. Normatif olarak anlamlı, önemlidir, mükemmel ve kolayca kamu politikası ölçütüyle yaptırıma tabi tutulabilir ve fakat sistematik olarak ölçümü oldukça güç olduğu vurgulanmaktadir.

Kurumsal değişim ve teknoloji transferinin etkililiği de bir diğer inceleme başlığı olabilir. Bu durumda, kamu yönetimi ve üniversitenin kurumsal gelişim boyutları ve işleyiş ve eşgüdüm meseleleri de olabileceği anımsanabilir. Ekonomik İşbirliği ve Kalkınma Teşkilatı (Organization for Economic Cooperation and Development-OECD), Sanayi ve Teknoloji Bakanlığl, Türkiye Bilimsel ve Teknolojik Araştırma Kurumu (TÜBITAK), Türk Patent ve Marka Kurumu, Türk Standartları Enstitüsü (TSE), Ticaret Bakanlığg, Tüketicinin Korunması ve Piyasa Gözetimi Genel Müdürlüğü, Türkiye Ihhracat Kredi Bankası A.Ş. (Türk Eximbank), Rekabet Kurumu, üniversiteler, büyük şirketler, Hazine, Türk Telekom gibi kuruluşların işbirliği ve eşgüdümü gerekebilir. Bu karmaşık ve çok boyutlu konuları, 'ekonomi ve teknoloji politikası' konulu' ${ }^{1}$ konferanslarda tartışmayı sürdürmek yararlı olabilir. Türkiye’nin “yeni bir teknolojik dönüşüm evresinde, zayıf ulusal yenilik sistemi ile kuvvetli küresel değer zincirleri arasında, katma değeri yüksek ürün ve hizmet üretmekte zorlanan, katma değeri düşük teknolojilerde sıkışmış, bir diğer ifadeyle orta-teknoloji tuzağında bir ülke görüntüsü” verdiği belirtilmektedir (Akçomak, 2018).

AR-GE ve yenilik konusunda farkındalık ve finans desteği, devlet teşviki, patent teşviki, vergi teşviki gibi kamu politikası araçları olsa da yüksek teknoloji ürün ve süreç üretimi dönüşümünün 2000'li yıllardan günümüze henüz sağlanamadığına dikkat çekilmekte, uygulanan kamu politikalarının değerlendirilmediğine de işaret edilmektedir. Türkiye'de, 2000'li yıllardan günümüze bilim, teknoloji ve yenilik (BTY) politikası dört başlıkta değerlendirildiğinde:

1. Nicelik-Nitelik denge arayışında nicelik odaklı, teknoparkların kurulması ve parasal desteklere dayalı kısa sürede bir ölçek (sayısal büyüklük) hedefli, devletin düzenleyici rolü, 2011 sonrası Teknoloji Transfer Ofislerinin (TTO) kurulmasıyla, parasal destek ve girişimi hızlandıran programlar ortaya konmuştur. Teknopark, TTO, kuluçka ve hızlandırıcı sayıları ve bu ara-yüzlerden faydalanan firma ve girişimci, proje, patent ve ARGE personeli sayısı artmıştır (Yereli, 2008). Nicel ölçekte başarı olsa da aslında çok büyük ölçek değildir. Ayrıca, yurtdışına doktora öğrencisi gönderilmesi 1960'larda planlanan 3000 hedefi 500'de kalmıştır, sistematik artış en azından 1000 gibi daha uygulanabilir bir sayı ve kritik-etki kapasitesi gözetilebilir (Oğuztürk, 2004). Asıl itici-gücün kamu mu-özel kesim mi tercihleri arasında 1950'lerden günümüze salınan sarkaç, daha etkili-uygun-üretken-

Örneğin bkz.: 'Economics and Technology Policy Conference organized by the Center for Economic Policy Research, London: 1-2 September 1986. 
yönetilebilir işbirliği yönetim-modellerinin gelişmesi yönünde çalışmalara ihtiyaç olduğu izlenimi vermektedir.

2. Yaratıcılığa meydan veren sistem kurgulanmalı, yaratıcılığı, girişimciliği, yenilikçiliği esas alan yeni bir eğitim felsefesi ve eğitim programı önkoşulu sağlanmalıdır (Bilim ve Teknoloji Politikaları Araştırma Merkezi, 2018). Etkileşim eksikliği de sorun olarak sıralanmaktadır. Katma değerli ileri teknoloji yeni ürün ve süreç üretmek, beş unsurun etkileşimiyle olasıdır: Fikir - Araştırma - Uygulama - Ticarileştirme - Pazarlama

Türkiye'de, ara-yüzler (teknoloji geliştirme bölgeleri, teknoparklar, TTO’lar ve hızlandırıcılar), kısa zamanda sonuç vereceği düşünülen uygulama ve ticarileştirmeye odaklandığından, firma ve üniversitelere sağlanan AR-GE ile uygulama ve ticarileştirme desteklerinin eşgüdümünün sağlanamadığı ve yeni ürün pazarlanması aşamasının desteklenmediği, "fikir yaratma aşamasının göz ardı edilmesi eleştirilmektedir. Yaratıcılığın ön planda olduğu analitik düşünme, soru sorma ve problem çözme yeteneklerinin gelişmesine olanak sağlayan bir okul öncesi eğitim ve örgün eğitim sistemi önemlidir. Ancak eğitim sisteminde sayısız ve plansız değişikliklerin yardımcı olamadığı gösterilmektedir.

3. Eşitsizlikler - teknoloji edinme, kullanma ve geliştirmede bölgesel ve sektörel eşitsizlik giderilmelidir.

4. Ölçme ve Değerlendirme; politikaların nicel ya da nitel etki analizi yapılmalıdır. Politika araçlarının Ar-Ge ve yenilik faaliyet ve harcamalarının etkisi analiz edilmelidir. Uygulama eksikliği ki - 1960’lı yıllar planlı dönemden günümüze, birçok ilke ve hedefin kalkınma doğrultusunda uygulamaya geçemediği G. Kore ile aramızdaki fark olarak saptanmakta, bunun bir nedeni büyük yatırım gerektirmesidir, kamu yönetiminin kararlılığı, vizyonu, bilim ve teknoloji kültürünün gelişmesi de gerekebilir (Dağlı \& Oğuztürk, 2018) belirlenmesi ve çözüm yolları aranmasında, sağlıklı veri toplanması, kurumlar ve araştırmacılarla paylaşılması, kamu kaynakları ile toplanan verinin, kurallar çerçevesinde kamuyla paylaşılması doğaldır.

Ar-Ge ve yenilik faaliyetlerinin çoğunlukla ürün geliştirmeye odaklandığ 1 , yenilik ortaya çıkarabilecek niteliğe sahip araştırmacı ve araştırma ortamı sağlanamadığı, yenilik sürecini baştan-sona fonlayacak kurumsal altyapının bulunmadığı vurgulanmaktadır.

Dünyada eğilimlerin, teknoloji politikasında devletin etkinliğinin arttığı, devlete düzenleyici rolden fazlasının öngörüldüğü misyon odaklı bir anlayışa geçtiği, teknoloji politikasının her paradigmada döngüsü, her teknolojik paradigmanın başlangıcında bilim politikaları; sonrasında da sırasıyla teknoloji, sanayi ve yenilik politikalarının ön plana çıktığı gösterilmektedir.

Ekonomik ve toplumsal yapının da teknolojiyle dönüşeceği politikalar tasarlanması, hukukun üstünlüğü ilkesiyle iktisadi güven ortamı, kamu yönetiminin etkin olarak teknoloji yönü ve yayılma hızını belirlemesi, ekosistemdeki kurumların yeniden yapılandırılması önerilmektedir. Bu alanlardaki ilerlemelerin, "Yenilikçilik Indeksi" (Innovation Index) gibi göstergelerle de değerlendirilebilmesi ve izlenebilmesi olasıdır. Sosyoekonomik gelişmede 
bir çok alt-başlıkta olduğu gibi, sistemli gelişmeler alt-sistemlerin etkileşiminden de sinerji oluşturabilmekte ve/veya olumlu-olumsuz değişkenler ve etkilerin diğer alt-sistemleri etkileyebileceği anımsanmalıdır. Nitekim ekonomide ya da kamu yönetiminde istikrar (burada söz edilen, yönetim ve sistem kuraminda değinilen "homeostatis”: öz-denge, dengeleşim ve dinamik-dengedir), AR-GE istikrarını etkileyebilir. Ülkemizde potansiyelin olduğu, ancak geliştirilmesi gereği üzerinde durulabilir. Kamu destek sistemlerinin etkinliğinin ölçüm metodolojisi geliştirilebileceği gibi; yeni kurulan tekno-girişim firmalarının (start-ups) nasıl seçilip destekleneceği usul ve esaslarının da daha rafine hale gelmesi mümkün olabilir. Kamusal bütçenin daha etkin, verimli ve etkili kullanımının yol ve yöntemlerinin geliştirilmesi de bir "sürekli gelişim” süreci içerisinde olgunluğa erişebilir. Bütüncül yaklaşımlarla ülkenin ekonomik kalkınması ve toplumsal gelişimi daha somut adımlarla gerçekleşebileceğinden, ilerleme ve "inkişaf”" daha tutarlı biçimde sağlanabilir.

Bir diğer analiz edilmesi gereken konu, "Doğrudan Yabancı Sermaye Yatırımları (DYSY) (Foreign Direct Investments - FDI) kaynaklı teknoloji yayılımlarını ölçmek ve yerel firmaların uluslararasılaşması ilişkisinde teknoloji yayılımlarının dolaylı etkilerinin incelenmesidir. Bu konuyu irdelemek üzere ele alan bir araştırma, şirketlerdeki yabancı sermaye oranı ile yerli ve yabancı şirketler arasındaki teknoloji açığının teknolojik yayılım üzerindeki düzenleyici rolünü de değerlendirmiştir. Türk imalat sanayinde 18 farklı sektörde faaliyet gösteren 95 yabancı sermayeli firma analiz bulguları, teknoloji yayılımının yerel firmaların patent yoğunlukları üzerinde kısmi bir olumlu etkiye sahip olurken; işgücü verimliliği düzeyinde ise olumsuz etkisini ortaya koymaktadır. DYSY kaynaklı teknoloji yayılımlarında teknoloji açığının önemli düzenleyici etken olduğu görülmekle birlikte, teknoloji açığının sektördeki DYSY yoğunluğu ile yerel firmaların uluslararasılaşması arasındaki ilişkide sadece patent yoğunluğu üzerinden sınırlı bir dolaylı etki yarattığı ortaya konmaktadır (Nas \& Şahin, 2018). Dolayısıyla, "yerli” teknoloji yatırımının öncelik ve katkısının önemi anlaşılabilir. Diğer taraftan unutulmamalıdır ki beşerî sermaye düzeyi ile firma üretkenlikleri arasında da pozitif doğrusal bir ilişki mevcuttur. Bu bağlamda katma değeri yüksek ve kaliteli üretim için yüksek kaliteli iş gücünün istihdamı elzemdir. Türkiye, beşerî sermaye endeksindeki sıralamada 60,3 değeri ile 130 ülke arasında 75. pozisyonda gözükmektedir (Güneş ve Akın: 2019). Dolaysıyla Türkiye'deki gerekli beşerî sermayenin nispi eksikliğinin yabancı sermaye yatırımının katma değeri yüksek üretim alanlarına yeteri kadar kanalize olamamasına sebep olduğuna işaret edilmesi de mümkündür. Bu durumun teknoloji transferine etkisi negatif olarak saptanmıştır. Ancak, farklı araştırma ve yaklaşımlarla daha bütüncül analiz ihtiyacı olduğu da belirtilmelidir.

Nitekim, diğer bir açıdan bakıldığında ise, araştırma geliştirme (AR-GE) harcamalarının doğrudan yabancı yatırım (DYSY) girişi üzerindeki etkisi, 1990-2013 dönemine ait veriler kullanılarak, sınır testi yaklaşımıyla araştırılmış, uzun dönemde $A R-G E$ harcamaları ile doğrudan yabancı yatırım girişi arasında anlamlı bir ilişki bulunmuştur (Yaylalı \& Karaca, 2014). Kısa dönem analizinde ise AR-GE harcamalarının doğrudan yabancı yatırım girişini cari dönemde artırmasına rağmen bir dönem sonra azalttığı bulgusu tespit edilmiştir. 
DYSY firma üretkenlik etkisi konusunda yükselen ekonomilerde (Bulgaristan, Romanya ve Polonya örnekleri) bir araştırma, yabancı firmaların daha iyi performans sergilemesi ve yerli firmalara yayılma etkisini sorgulamıştır (Konings, 2001). Yalnızca Polonya'da yabancı firmalar daha iyi performans sergilemiştir, pozitif yayılmayı üç ülkede de bulgulamamıştır. Bulgaristan ve Romanya'da negatif yayılma olmuş; Polonya'da ise yayılma görülmemiştir. Olumsuz bir rekabetin, olumlu teknoloji etkisini baskıladığı belirtilmektedir.

Çevre korunması bakımından, sera gazı tehdidini karbondioksit payı-küresel sermaye hareketi ve Türkiye'ye gelen doğrudan yabancı yatırımın çevre kalitesine etkisini inceleyen bir çalışma, Türkiye için doğrudan yabancı yatırım akımları ile karbondioksit sürümü arasındaki ilişkiyi incelemiş, 1980-2011 dönemini kapsamıştır (Yaylalı vd., 2015). Sınır testi sonuçlarına göre, Türkiye için doğrudan yabancı yatırım akımları ile $\mathrm{CO}_{2}$ serileri arasında eş-bütünleşme ilişkisi yoktur, uzun dönemde DYSY akımları ile $\mathrm{CO}_{2}$ sürümünün birlikte hareket etmediği belirtilmiştir.

Teknoloji transferi mümkün, ama otomatik bir süreç değildir (Kaya, 2006): Teknoloji transferinde, ev sahibi ülke ve ev sahibi ülkenin endüstrilerinin doğası, kümelenmesi ve politik çevrenin koşulları, yabancı ve yerli firmalar arasında teknolojik düzey farklılığı etkili olabilir. Kaya (2006)'nın değindiği Letchumanan ve Kodama'nın 2000 araştırmasına göre, yabancı sermaye gelişmekte olan ülkelere çevre dostu ürün ve teknolojileri taşımaktadır. Yine Kaya (2006)'nın referans verdiği Görg ve Greenaway (2004); gelişmiş, gelişmekte olan ve geçiş-dönemi ekonomilerinde, teknoloji transferi - verimlilik, ücretler ve ihracat konularını kapsayan 40 araştırmanın sonuçlarına göre, bu 40 çalışmanın yarısının pozitif etki sonucu olduğunu belirtmektedir. Türkiye'de kamu politikası 1980'lerden beri DYSY'1n yurtdışından teknoloji transferi konusunda önemli bir araç olduğunu vurgulamış ve bu yatırımları çekmek için çeşitli teşvikler uygulamıştır. Değişen koşullar altında, Türkiye'de teknoloji transferi konusunda destekleyici politikalar üretilmesi, gerekli altyapının kurulması, uzun dönemli bakış açısıyla konunun değerlendirilmesi, kamusal destekle Türk şirketlerin de AR-GE alanında kendi altyapılarını kurması ve yaratıcılı̆̆ı özendirici politikalar üretmesi önerilmektedir (Kaya, 2006: 100).

Genel anlamda etkileşimin fayda yaratma ve gelişim konusunda çarpan etkisi yarattığı iddia edilebilir. Çünkü bu şekilde bilgi yayılımı ve iş birliği imkânları daha güçlü olarak ortaya çıkmaktadır. Aynı kapsamda, teknopark yönetimleri tarafindan yapılan çalışmaların, yürütülen faaliyetlerin ve düzenlenen programların temelinin bu etkileşimlerin katkısını arttırmaya yönelik olduğu düşünülebilir.

Söz konusu çıkarımlardan teknopark yönetimlerinin odak noktasının şirketlere yönelik politika ve faaliyetler olduğu açıktır. Başka bir deyişle, mikro düzeyde teknokentler bünyelerinde bulundurdukları AR-GE şirketlerinin araştırma-geliştirme faaliyetlerine destek vermek ve onların AR-GE çıktısı olan ürünlerini ticarileştirebilmelerine imkân sağlamak amacını gütmektedirler. $\mathrm{Bu}$ doğrultuda teknokentlerin kullanabilecekleri birçok araç mevcuttur. Dolaysıyla profesyonel teknopark yönetimlerinin başarısının bu araçları 
çeşitlendirmede ve etkin kullanımda gösterdikleri beceri ile ilintili olduğunu değerlendirmek yanlış bir yaklaşım olmaz.

Teknoparkların elindeki birinci araç makro düzeydeki teknoloji ve yenilik politikası ile bağlantılı uygulamaları kapsar. Burada ifade edilen kamu politikaları genellikle devletin teknoparklarda yer alan şirketlerin faydalanması için sunduğu teşvikleri ihtiva eden paketlerdir. Bu teşvikler, Türkiye örneğinde de olduğu gibi, vergi ve ücret ödemelerinde sağlanan avantajları kapsayabilirler. Buna benzer bir şekilde, teknolojik ürün üretimi için yatırım indirimleri, ya da AR-GE amaçlı ithalat teşvikleri gibi teknopark firmalarının faydalanabileceği başka teşvik çeşitlerinden de söz edilebilir. Bunun haricinde teknoparklarda olsun ya da olmasın, AR-GE üretimi ve ticarileştirilmesi ile uğraşan tüm firmalara verilen genel maksatlı hibe destekleri de kamunun AR-GE ve teknoloji politikasının bir parçası olarak ortaya çıkmaktadırlar. Ancak, sözü geçen bu teşviklerin hepsi tüm teknoparklar için eşit düzeyde geçerlidir. Başka bir anlamda, birinci kamu politikası aracının kullanılmasında teknopark yönetimlerinin rolünün mevcut ve yenilenen teşviklerden paydaşlarını etkin bir şekilde bilgilendirmeleri ve mevzuat konularına açıklık getirmeleri ile ilintili faaliyetlerle sınırlı olduğu düşünülebilir.

Profesyonel teknopark yönetimleri aynı zamanda emlak işletmecisi görevini de ifa etmektedirler. Çünkü tesislerinde barındırdıkları AR-GE şirketleri aynı zamanda onların kiracısı niteliğindedir. Bu anlamda yönetim ekibinin işletmecilik açısından müşterilerine sürekli olarak huzurlu, sağlıklı ve konforlu bir ortam sağlamaları, şirketlerde çalışan insan kaynaklarının performansları açısından son derece önemlidir. Burada sözü edilen ölçütün yerine gelmesi hem teknoparkın maddi imkânları hem de yönetim ekibinin gerekli hizmetleri tedarik etmelerindeki yetenek ve becerilerine bağlıdır. Teknoparkların bu rolü niteliği etkileyen ancak daha çok nicelik içerikli hizmetler olarak da tanımlanabilir.

Niteliği yüksek ölçüde etkilemesi beklenen ve nitelik içeriği nispeten daha yüksek olan teknopark hizmetleri, teknoparkların etkileşim özelliğini merkeze alan ve böylelikle şirketlerin AR-GE kapasitesi ve yenilik kabiliyetlerini arttırmayı hedefler vaziyettedir. İstenilen hedeflere ulaşmadaki başarının ölçüsünün teknoparkların etkinliği olduğu kadar en az buralardaki şirketlerin ve başta üniversiteler olmak üzere, etkileşim içinde bulundukları tüm kurumların potansiyelleri ile de ilgili olduğu düşünülebilir.

Sözü geçen bu hizmetlere, yenilik kültürünü arttırmaya, şirketlerin üniversite - kamu kuruluşları, AR-GE merkezleri ile işbirliğini büyütmeye, şirketlerin iç ve dış pazar oyuncuları ile işbirliğini arttırmaya, onların iş ağlarını geliştirmelerine katkı sağlamaya, girişimcilik yapmak isteyen kişi ve şirketleri eğitmeye, onların finansal kaynaklara erişimini sağlamaya yönelik faaliyetler örnek olarak verilebilir.

Diğer taraftan teknoparkların etkin işleyişini, şirketlerin performans ve çıktıları üzerinden yapmak etkinlik analizi ile mümkündür ancak aynı anlamda da çok zordur. Türkiye' de bu konuda subjektif ve objektif verilere dayalı bazı çalışmalar mevcut olmakla birlikte daha keskin bir değerlendirmede bulunulabilmesi için özellikle objektif verilere dayalı kapsamlı etki analizi çalışmalarının yapılmasına ihtiyaç olduğu da açıktır. Çünkü 
teknoparklardaki şirketlerin toplam satışları, ihracatları, aldıkları yabancı sermaye yatırımı, yürüttükleri AR-GE projesi sayısı, kurulan akademisyen şirket sayısı ya da üretilen patent miktarı gibi veriler, teknoparkların etkileri ya da etkinlikleri hakkında tam bir fikir vermemektedir.

\section{Türkiye'deki Teknoparklara Genel Bakış}

Türkiye'de teknoparkların tarihi 1991 yılında İstanbul Teknik Üniversitesi (İTÜ)’nde ve 1992 yllında Ortadoğu Teknik Üniversitesi (ODTÜ)'nde kurulan Teknoloji Geliştirme Merkezleri (TEKMER)'ne dayanmaktadır. Bunların kuruluşu ile T.C. Küçük ve Orta Ölçekli Işsletmeleri Geliştirme ve Destekleme İdaresi Başkanlı̆̆ (KOSGEB)'in koordinasyonu altında, Küçük ve Orta Büyüklükteki İşletmeler (yıllık 250 kişiden az işçi istihdam eden KOBI')'in üniversiteler ile bir araya gelerek ortak ARGE faaliyetleri yürütmesi amaçlanmıştır (TEKMER Nedir, 2019). Daha sonra 2001 yılında çıkarılan 4691 sayılı Teknoloji Geliştirme Bölgeleri Kanunu ile aynı yıl ODTÜ Teknokent, Türkiye'nin ilk resmi olarak kurulan teknokenti olarak ortaya çıkmıştır.

Türkiye' de Aralık 2019 itibari ile 85 tane teknopark, kanuni altyapısını tamamlamış olup 67 tanesi aktif halde faaliyetlerini sürdürmektedir. Bunların 10'u Ankara'da, 11'i İstanbul' da ve 4'ü de İzmir'de bulunmaktadır (T.C. Sanayi ve Teknoloji Bakanlığı [STB], 2020).

Türkiye'de Teknoparklar için genel anlamda devletin sağladığı teşvikler ile cazibe yaratılmış ve firmalara yönelik çeşitli konularda (mevzuat, iş kapasitesi, iş becerileri, işbirlikleri ve ARGE faaliyetlerini destekleme, satışları arttırma amaçlı) bilgilendirme, destek ve eğitim içerikli çeşitli programlar yürütülmüş ve teknoparklarla kurumlar arası etkileşimi artıracak çeşitli çalışmalarda bulunulmuştur.

Sanayi ve Teknoloji Bakanlı̆̆ı'nın Aralık 2019 verilerine göre Türkiye'de toplam 67 tane teknoparkta 5,506 firma toplam 14.85 Milyar Dolarlık satış ve 4.4 Milyar Dolarlık ihracat gerçekleştirmiştir. Ekonomik kalkınmada istihdama katkı açısından bakıldığında ise yine aynı tarih itibari ile teknoparklarda toplam istihdam edilen kişi sayısı 56,689'dur (STB, 2020).

Türkiye'deki teknoparkların sektör dağılımı NA-CE kodlarına göre gruplandırılmaktadır. Bu gruplandırma incelendiğinde:

- Programlama ve yazilım \%43,23

- Bilgisayar- yazılım-donanım ile ilgili ticari ve danışmanlık faaliyetleri \%6,25

- Sağlik ve bio-teknoloji \%3,11

- Elektronik donanım imalatı \%1,04

- Enerji, genel mühendislik danışmanlık \%4,89

- Tarım \%1,49 ve

- Makina imalatı \%1,11 gibi göze çarpan sektör oranları sıralanabilir (STB, 2020). 
2001-2016 yılları arası verilere dayanarak teknoparkların gelişimi incelendiğinde yıllara göre artan teknopark sayılarındaki çoğalmaya (Şekil: 1) paralel olarak ihracat ve istihdam sayılarında da artış göze çarpmaktadır (Tablo: 1). Artan teknopark sayısı oranlarında yer alan şirket sayılarında da bir yükselişi beraberinde getirdiği için bu artışın doğal olduğu beklenebilir. Ancak sözü geçen verilerdeki artışın hangi oranda mevcut teknopark şirketlerinin üretkenlik ve verimliliklerinin yükselişinden geldiğini yalnızca bu tablodaki verilerden hesaplamak mümkün değildir.

Tablo: 1

Türkiye'de Teknoparkların Gelişimi

\begin{tabular}{|c|c|c|c|c|c|c|c|c|c|c|c|}
\hline Yil & $\begin{array}{l}\text { Aktif } \\
\text { TGB } \\
\text { Sayis! }\end{array}$ & $\begin{array}{l}\text { Firma } \\
\text { Sayısı }\end{array}$ & $\begin{array}{l}\text { Toplam } \\
\text { çalışan } \\
\text { Sayısı }\end{array}$ & $\begin{array}{l}\text { Ortalama } \\
\text { çalı̧an } \\
\text { Sayısı }\end{array}$ & $\begin{array}{l}\text { Akademik } \\
\text { Girișimci } \\
\text { Sayısı }\end{array}$ & $\begin{array}{l}\text { Tamamlanan } \\
\text { Proje Sayısı } \\
\text { (Kom.) }\end{array}$ & $\begin{array}{l}\text { Devam } \\
\text { Eden Proje } \\
\text { Sayısı }\end{array}$ & $\begin{array}{l}\text { Ihracat } \\
\text { Milyon } \\
\text { Dolar } \\
\text { (KOm.) }\end{array}$ & $\begin{array}{l}\text { Toplarn } \\
\text { Satışlar } \\
\text { (Milyon } \\
\mathrm{TL})(\mathrm{KOm} \text {.) }\end{array}$ & $\begin{array}{l}\text { Patent } \\
\text { Başvuru } \\
\text { (Kom.) }\end{array}$ & $\begin{array}{l}\text { Patent } \\
\text { Tescil } \\
\text { (KOm.) }\end{array}$ \\
\hline 2001 & 2 & 60 & 240 & 4 & 7 & 10 & 90 & 3 & 50 & 4 & 3 \\
\hline 2002 & 2 & 80 & 300 & 3,8 & 10 & 25 & 140 & 5 & 200 & 7 & 9 \\
\hline 2003 & 3 & 135 & 463 & 3,4 & 15 & 78 & 400 & 10 & 300 & 10 & 15 \\
\hline 2004 & 6 & 324 & 3.795 & 11,7 & 23 & 187 & 948 & 35 & 450 & 18 & 30 \\
\hline 2005 & 11 & 468 & 6.489 & 13,9 & 30 & 398 & 1.300 & 80 & 960 & 29 & 55 \\
\hline 2006 & 14 & 546 & 9.081 & 16,6 & 47 & 600 & 1.939 & 171 & 2.000 & 60 & 97 \\
\hline 2007 & 18 & 802 & 9.770 & 12,2 & 87 & 2.156 & 1.504 & 340 & 4.000 & 120 & 149 \\
\hline 2008 & 18 & 1.154 & 11.093 & 9,6 & 153 & 4.211 & 3.069 & 406 & 6.000 & 230 & 293 \\
\hline 2009 & 23 & 1.254 & 11.021 & 8,8 & 217 & 5.874 & 3.403 & 501 & 7.400 & 244 & 297 \\
\hline 2010 & 28 & 1.515 & 13.397 & 8,8 & 279 & 7.179 & 4.102 & 520 & 9.200 & 239 & 275 \\
\hline 2011 & 32 & 1.800 & 15.822 & 8,8 & 373 & 8.052 & 4.979 & 543 & 10.100 & 265 & 282 \\
\hline 2012 & 34 & 2.174 & 19.498 & 9 & 497 & 10.661 & 5.703 & 890 & 11.590 & 393 & 329 \\
\hline 2013 & 39 & 2.569 & 27.224 & 10,6 & 382 & 11.247 & 6.997 & 1.511 & 13.832 & 432 & 268 \\
\hline 2014 & 42 & 3.016 & 30.729 & 10,2 & 542 & 14.859 & 7.139 & 1.789 & 23.056 & 687 & 410 \\
\hline 2015 & 49 & 3.744 & 38.239 & 10,2 & 714 & 18.318 & 8.525 & 2.333 & 32.068 & 1.022 & 591 \\
\hline 2016 & 51 & 4.217 & 40.172 & 9,8 & 783 & 20.734 & 8.593 & 2.335 & 35.511 & 1.125 & 649 \\
\hline
\end{tabular}

Kaynak: Cansiz, 2017: 41.

Sürdürülebilir kalkınma gelecek planlaması yapan kalkınma ajanslarının, üniversite hedefleri belirlenmesinde rol oynayabilir. İlgili kurumların hedefsizliği ya da eksikliği varsa giderilebilmelidir:

- Kurumlar arası eşgüdüm,

- Ortak hedef,

- Önceliğe göre yatırım,

- Üniversite sanayi işbirliğinde yeterli altyapı ve laboratuvar,

- KOBÍ'lere ileri teknoloji ortami,

- Katma değerli üretim desteği,

- Ülke ve bölge sorununa çözümün desteklenmesi, 
- Kalkınmaya katk1,

- Disiplinler arası araştırma,

- Sanayide problem çözümü teşviki,

- Fakülte ve bölümler arası ihtiyaç analizi,

- Sürdürülebilir gelişme için bölgesel ve yerel hedef doğrultulu çalışılması,

- Üniversite tarafindan üniversite içinde teknokent kurulabilmesi,

- Girişimcilik ve yenilikçilik desteği,

- Üniversitenin teknokent firmalarına tanitımı,

- Üniversite alt yapısının etkin kullanımı,

- Döner sermaye mevzuatının akademik personel katılımını desteklemesi

- gibi kurumsal süreçler öne çıkmaktadır (TÜBİTAK - ADANA - ÜSAM, 2005: 68-70).

Şekil: 1

Yıllara Göre Aktif Teknopark Sayıları (2017)

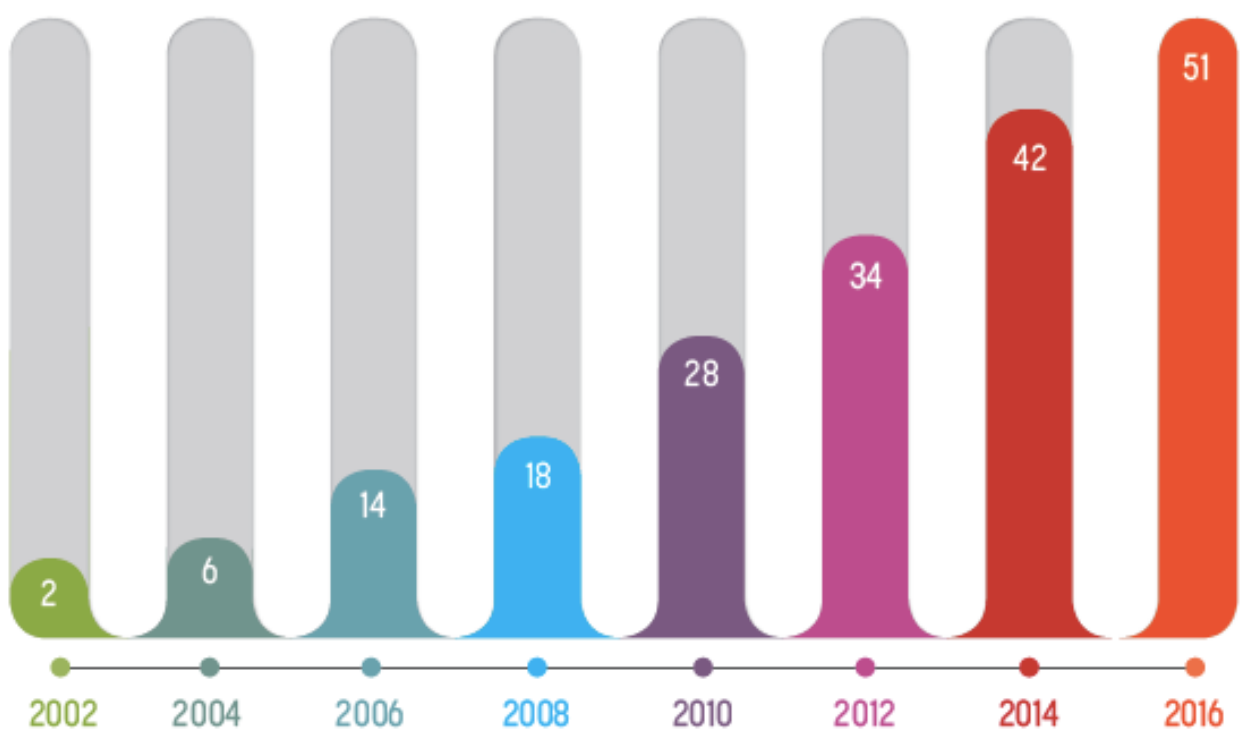

Kaynak: Cansiz, 2017: 41.

Türkiye'deki teknoparklarda Aralık 2019 itibari ile tamamlanan proje sayısı 34.244'dür (STB, 2019). Ancak bu projelerin çıktılarının Türkiye'nin yüksek teknoloji ürünleri ihracatına henüz istenilen katkıy yaptıklarını söylemek mümkün gözükmemektedir. Benzer şekilde üniversitelerdeki potansiyel bilgi ve çalışmaların Teknoloji Transfer Ofisleri (TTO) ya da akademisyenlerin teknoparklarda kurdukları şirketler vasıtası ile ticarileştirmeleri konusundaki istatistiki veriler de çok düşük seviyede bulunmaktadır. 
$O E C D$ tarafından ülkelerin teknoloji yoğunluklarını ölçmek ve teknoloji geliştirme kapasitelerini belirlemek maksadiyla tanımlanan sinıflandırmaya (ISIC Rev 3. Teknoloji Yoğunluğu Tanımlaması'na [OECD, 2011]) göre 1996 ve 2018 yılları arasında Türkiye'nin yüksek teknoloji ürün ihracatının toplam imalat sanayi ihracatına oranı $\% 2$ seviyelerinde seyretmektedir. Aynı yıllar için düşük teknoloji ürünlerinin toplam imalat sanayi içerisindeki payı yüzde 50'den yüzde 30'a düşerken aynı oran düşük-orta teknoloji ürünleri için 18'den 25'e ve orta-yüksek teknoloji ürünleri için 17'den 36'ya yükselmiştir (Konak, 2018).

$\mathrm{Bu}$ tabloya göre Türkiye, düşük-orta ve orta-yüksek teknolojiler üreten bir ülke olarak sınıflandırılmaktadır. Ülkenin yüksek teknoloji ürünlerindeki ihracat payı olan yüzde 2-2.5 seviyeleri ise diğer $O E C D$ ülkelerine kıyasla çok düşük seviyelere işaret etmektedir (Şekil: 2).

Şekil: 2

\section{Bazı Ülkelerin Yüksek Teknoloji İhracatının Toplam İmalat İhracatı İçindeki Payı} (2017)

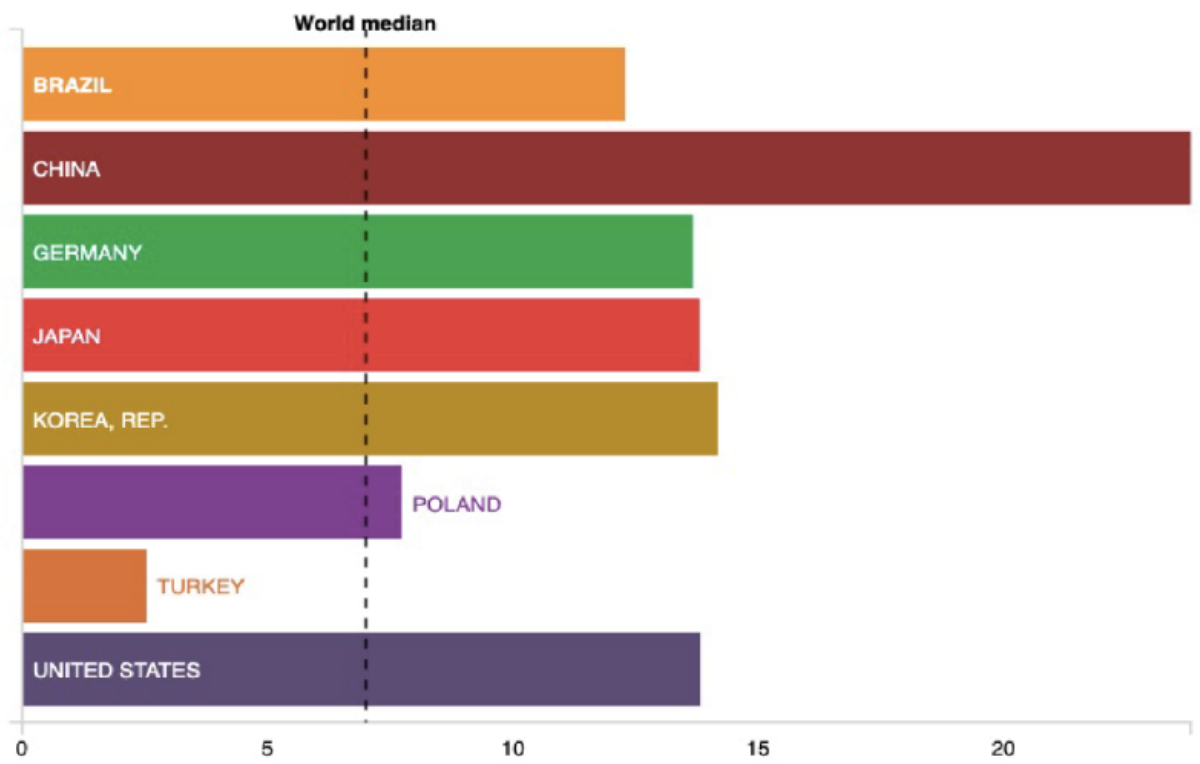

Kaynak: World Bank (Dünya Bankası) verilerine (World Bank, 2019) dayanılarak tarafimızca hesaplanmıştır.

Türkiye'deki teknoparklar için muhtelif teknoparklarda teknoparkların ve yönetim şirketlerinin firma performansları üzerine etkileri hakkında fikir oluşturmak için belli parametreleri esas alarak bir anket çalışması yürütülmüştür. Subjektif verilere dayanan bu çalışmada teknopark firmaları açısından kurumsal iş birliği, genel itibar durumlarl, yeni pazarlara erişim kapasiteleri ve kaliteli insan kaynağl istihdam etme, finans imkanlarına erişim kamu-üniversite-sanayi iş birliği kapasitesi ve ekonomik performanslarına katkı gibi parametreler esas alınarak bir ölçüm yapılmış ve bir fikir oluşturulmaya çalışılmıştır 
(Cansız, 2017:170-191). Bu sonuçlara göre, Türkiye'deki teknoparkların firmaların kapasite ve kabiliyetlerine belirli ölçüde katkı sağladıkları ancak bu katkının geliştirilmeye muhtaç ve yeteri seviyelerde olmadığı sonucuna ulaşılabilmektedir.

\section{3. İstatistiksel Analiz}

Çalışma bünyesinde Ankara ilinde 2 farklı teknoloji geliştirme bölgesinde yer alan; Gazi Teknopark ve Bilkent Cyberpark bünyesinde son 10 senedir faal olan ve ARGE faaliyetleri yürüten kuruluşların iktisadi verileri incelenmiştir. Bu kapsamda, ARGE kaynaklı ve dişı, yurt içi ve ihracat satış rakamları ve istihdam değişkenleri üzerinde son 10 y1l içindeki seyir değerlendirilmiştir. Ayrıca, bu değerlendirmeden yola çıkarak, söz konusu değişkenler için önümüzdeki iki (2) yılın öngörüleri yapılmış, gelecek döneme ilişkin çıkarımlarda bulunulmaya çalışılmıştır. Öngörüleri gerçekleştirmek için, Zaman serileri yöntemi kullanılmıştır. Algoritmalar ve veri ön değerlendirmeleri SAS 9.4 ve SAS Forecasting çözümü kullanılarak gerçekleştirilmiştir. 3 farklı algoritma öngörülerin hesaplanmasında kullanılmıştır. Süreçte en iyi modelin seçilmesi, ilgili modellerin MAPE (mean absolute percentage error) değerlerinin en düşük olmasına bağlı tutulmuştur. Böylece en düşük hata ile modelleme çalışmasının gerçekleştirilmesi hedeflenmiştir.

Yıllar bazında veri setinde yer alan satış değişkenleri USD cinsinden tutarları göstermektedir. Yıllar 2010 yılından başlamakla beraber bazı durumlarda 2011 yılı başlangıç olarak değerlendirilmiştir. Diğer yandan yıllar çeyrekler bazında 4 grupta zamansallaştırılmıştır. Buna göre 8 çeyrek için toplamda 2 yıllık öngörü çıktıları her bir satış grubu için aşağıda görselleştirilmiştir. Veri içeriğinde Gazi ve Bilkent teknoloji yerleşkelerinde ilgili yıllarda yer alan firmalara ait değerler bulunmaktadır.

Geçmiş satış tutarlarına ilişkin gözlemlerden yararlanarak satış türlerine göre 2020 ve 2021 yılları için satış tahminleri yapılmıştır.

Şekil: 3

Ar-Ge Yurtiçi Satış Tutarları 2020-2021 Satış Tahmin Grafiği

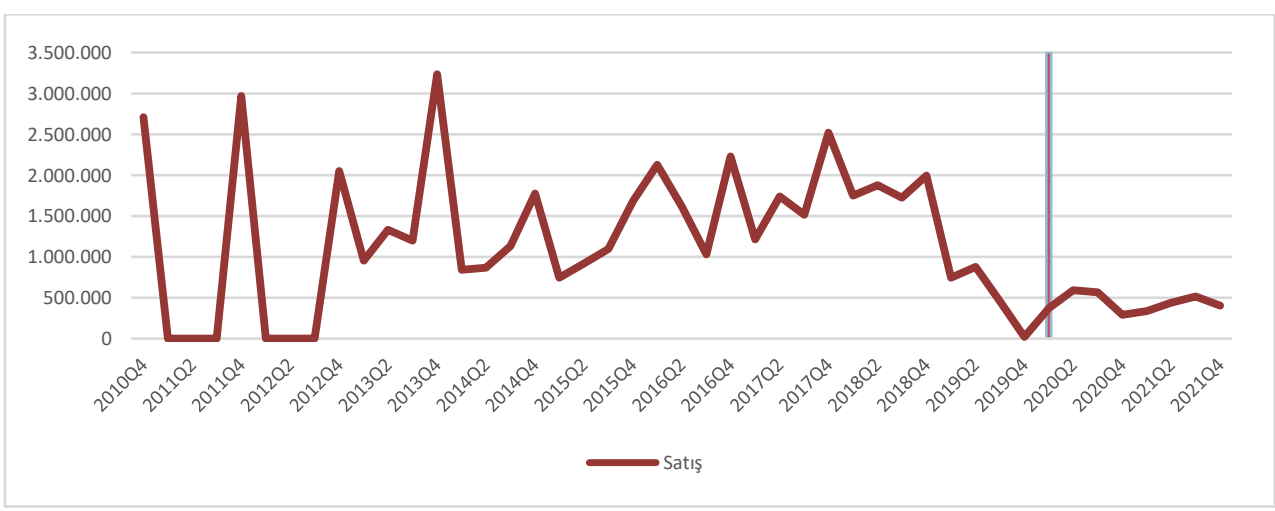

Kaynak: Gazi Teknopark ve Bilkent Cyberpark. 
$\mathrm{Bu}$ şirketler, belirli bir süre ayakta kalmayı başarmış durumdadırlar. Ancak genelde ARGE temelinde olsun olmasın proje-temelli çalışmaktadırlar ve Şekil: 3'teki gibi aşağıyukarı (up and down) bir gelişim çizgisi göstermeleri normal karşılanabilir. Bir ürün geliştirme amaçlı olduklarından, bir ay diğerini, bir çeyrek (quarter) diğerini, bir yıl diğerini tutmayabilir. Ayrıca, doğaldır ki, genel ekonominin seyir grafiğinin etkileri yansıyabilmektedir. Aşağıdaki (Şekil: 4) şekilde ihracata bakıldığında ise, teknoparkların değişik pazarlara açılma desteği ve "ara-yüz" görevi görme işlevinde nispeten başarılı oldukları yorumlanabilir.

Şekil: 4

\section{Ar-Ge Dışı Yurtiçi Satış Tutarları 2020-2021 Satış Tahmin Grafiği}

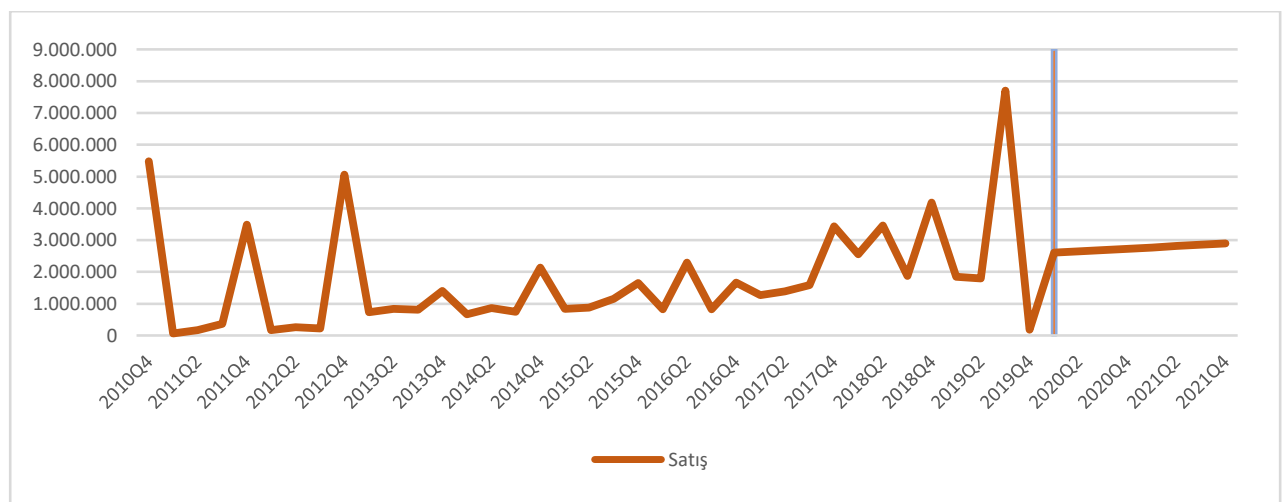

Kaynak: Gazi Teknopark ve Bilkent Cyberpark.

Dış dünyadaki ekonomik talebin nispeten yine Şekil: 5'te yansıdığı gibi daha geniş imkânlar ve ufuklar (pazar derinliği, daha fazla talep potansiyeli vb.) içerdiğinden iyi olabileceği de varsayılabilir.

\section{Şekil: 5}

\section{Ar-Ge İhracat Satış Tutarları 2020-2021 Satış Tahmin Grafiği}

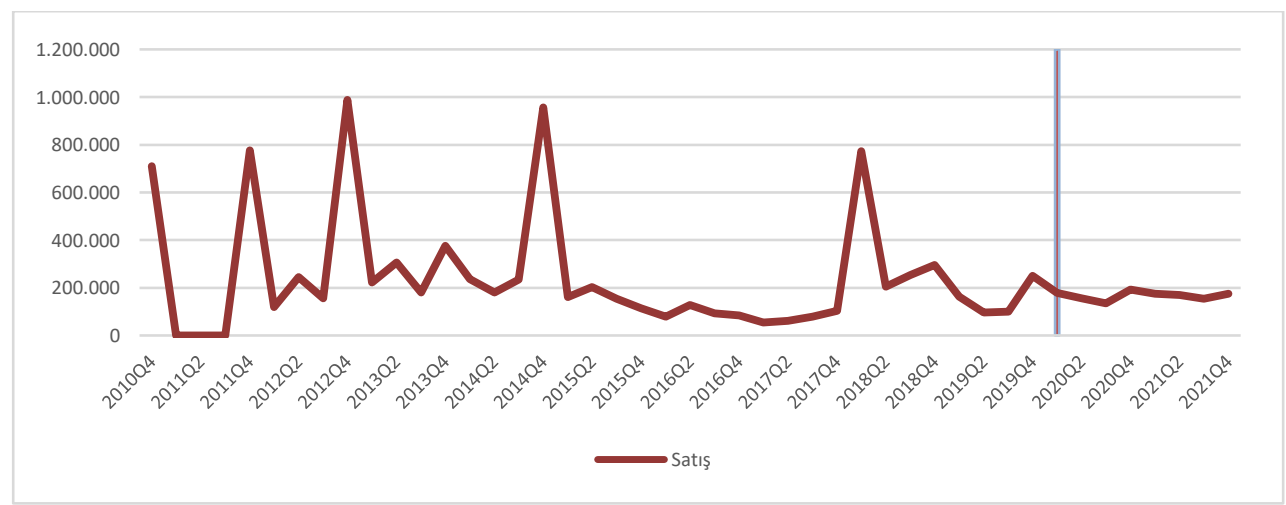

Kaynak: Gazi Teknopark ve Bilkent Cyberpark. 
$\mathrm{Bu}$ trendi en azından aynı tutabilmek ve de geliştirebilecek çalışmaların sürdürülmesinin yerinde olacağı saptanabilir. Nitekim Şekil 6'da yurtdışı satış grafiğinin, ARGE kaynaklı ve dışı ürünlerde farklılık gösterse (yaklaşık 1/6 düzeyinde) ve düşük seyretse de bir istikrar yakaladığı tahmin edilebilir.

\section{Şekil: 6}

\section{Ar-Ge Dışı İhracat Satış Tutarları 2020-2021 Satış Tahmin Grafiği}

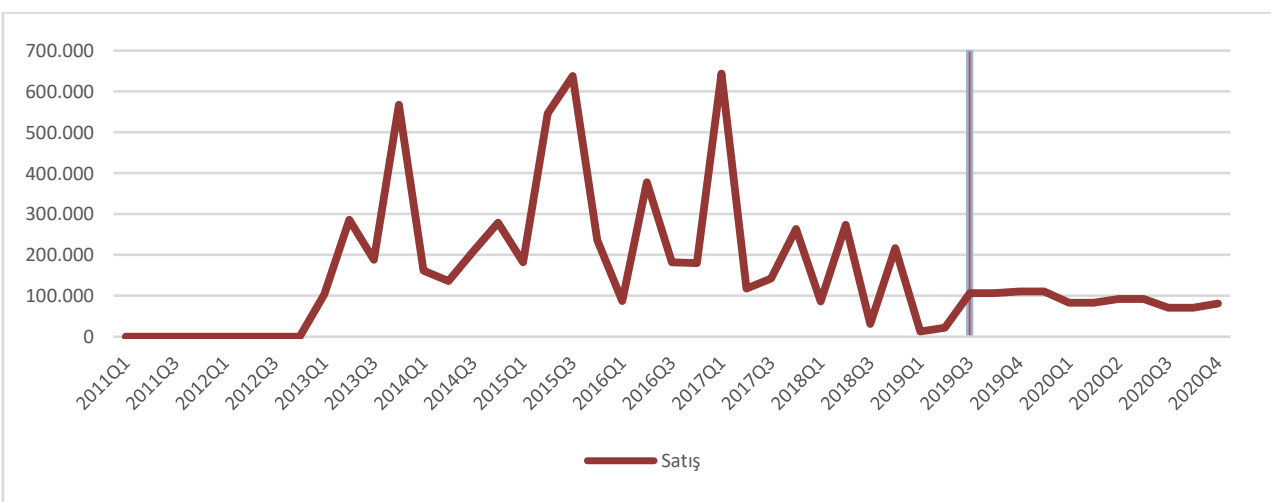

Kaynak: Gazi Teknopark ve Bilkent Cyberpark.

Yukarıdaki şekillerde, düşük ve istikrarlı bir düzeyde seyreden satış grafikleri, çeşitli ek yorumlara muhtaçtır. Tabi ki şirketlerin kapasitesinin de geliştirilmesi oldukça yararlı olabilir. Ülke geneli BTY (STI policy) politikaları ile ekonominin gerekleri açısından gözden geçirilmesi düşünülebilir. Özellikle teknopark şirketlerinin pazarlama unsurlarının desteklenmesi, diğer yandan da üniversite destekleriyle işbirliklerinin artırılması dikkate alınabilir. Yalnızca teşviklerin verilmesi olarak değil, daha bütüncü, işlevsel, rasyonel kamu politikaları, kuramsal bölümde de değinildiği gibi tartışılabilir.

Örneğin, Şekil: 7'de verilen aşağıdaki istihdam grafiğinde de bir düşüş gözlemlenmektedir. Ancak genel ekonominin yanı sıra, teknik-uzmanlık gerektiren alanlarda, şirketlerin durumunu ele almak gerekir. Bir de teknoloji-yoğun bir ivme ile ülke orta-gelir ve orta-teknoloji tuzağından kurtulmak üzere sıçramadan söz ediliyorsa, Türkiye'nin makro ekonomisine, teknoloji-yoğun ihracat bakımından yansıdığı söylenemeyebilir.

Yine de en azından, bu şirketlerin bir potansiyeli olduğu şekillerde görülmekte ve yakın gelecekte de belirli bir düzey sürdürülebilirlik sağlayacakları öngörülmektedir.

Özetlemek gerekirse:

- Hem satı̧s-pazarlama kabiliyeti,

- Hem kendine özgü (şahsina münhasır: unique) teknoloji geliştirme kapasitesi ya da kapasite sorunu var midır? 
- Hem de sorumluluğu yalnızca kamu desteği miktarı ya da düzeyinde aramak yeterli olmayabilir. Mesele yalnızca kamu teşviki değilse ki, olmayabilir, dolayısıyla, firma teknoloji üretimi kapasite sorunu söz konusu ise, bu sorunun atlanılmaması önerilebilir.

\section{Sekil: 7}

\section{İstihdam 2020-2021 Tahmin Grafiği}

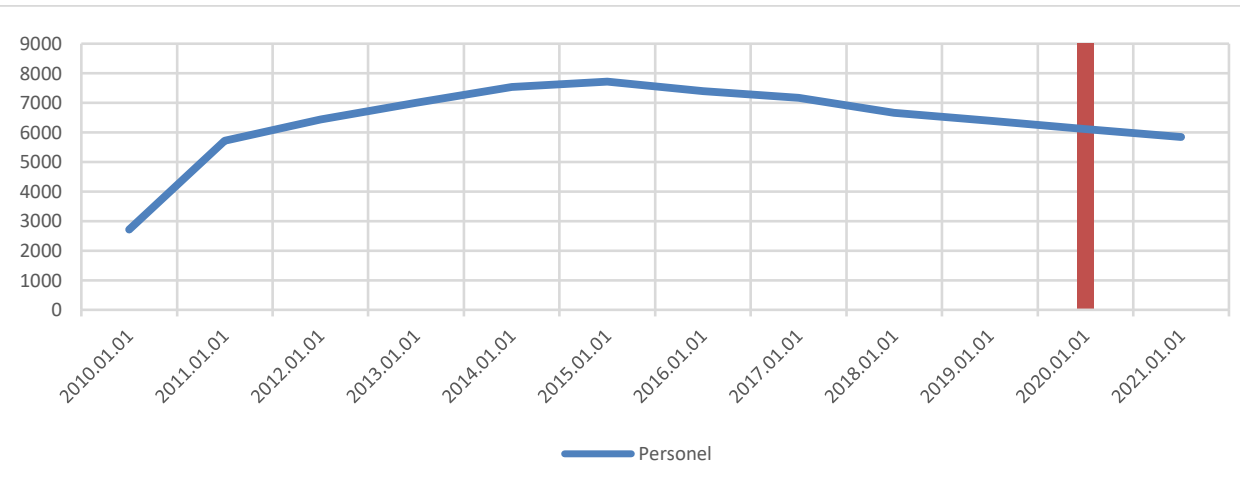

Kaynak: Gazi Teknopark ve Bilkent Cyberpark.

Yıllardır, 1990'lardan bu yana ve yasanın 2001'de çıkmasıyla teknoloji üretiminde teşviklerin arttığı dönem değerlendirildiğinde, resmin bütününü çıkarmak olasıdır. Şekiller ve grafikler, işin doğasındaki güçlükleri ve istikrarsızlıkları sergilemektedir. Uluslararası göstergeler ve Türkiye'nin veri seti için ayrıca ARGE İndeksi veya Yenilikçilik Índeksi (Innovation Index) gibi uluslararası karşılaştırmalar içeren veriler de ipuçları sunabilir.

\section{Sonuç}

"Kamu İşletmeciliği” bakış açısı ile "etkililik-uluslararasılaşma-şeffaflık” gibi ilkeler doğrultusunda, teknoparkların başarılı emlak işletmeciliğinin yanı sıra sundukları ofis ve sosyal hizmetlerinin kiracı şirketlere fayda yaratması kaçınılmazdır. Çünkü müşteri memnuniyeti, pozitif, huzurlu, konforlu ve rahat bir çalışma atmosferi şirketlerin verimini arttıracaktır. Bu yüzden teknopark yönetimlerinin gerekli hizmetleri sağlayacak ekip ve donanıma sahip olması önemlidir.

Aynı zamanda teknopark olgusu marka ve pazarlama ile ilişkili de bir konudur. Esas itibarı ile hem yurt içi hem de yurtdışı potansiyel pazarlarda teknoparkta yerleşik bir şirketin karşı taraf üzerinde pozitif algı oluşturduğu açıktır. Çünkü teknoparklarda yer alan şirketler ARGE ve yüksek teknoloji tabanlı kurumlar olarak değerlendirilmektedir.

Benzer şekilde, teknoparklarda yer alan firmaların genel olarak tanınırlığı ve görünürlüğü artmakta olup kamu nezdinde algılarında da pozitif bir artışın gözlemlendiğinden söz edilebilir. Dr. Mehmet Cansız'ın teknoparklar üzerine yaptığı subjektif verilere dayanan bir çalışmaya göre teknoparkların mevcudiyeti kurumlar arasında 
işbirliğine ve daha özelinde kamu - üniversite - sanayi iş birliğine pozitif katkı sağlamaktadır (Cans1z, 2017: 191, 199).

Öbür taraftan teknoparkların etkinliği somut çıktılar üzerinden tartışıldığında buradaki asıl mesele kamunun makro düzeydeki politikaları vasıtası ile sağladığ desteklerle bütünleşik olarak teknopark yönetici şirketlerinin mikro düzeyde sundukları nitelikli hizmetlerin etkinliğinin objektif ve subjektif ölçütler 1şığında ölçülmesi veya tayin edilmesidir. Başka bir deyişle amaç, sağlanan nitelikli hizmet ve desteklerin etkilerini değerlendirmeye yönelik yaklaşımları ortaya koymak olmalıdır. Fakat esas anlamda ölçüm zordur ve diğer ülke örneklerinden bilindiği üzere genel anlamda bilimin, ARGE ve teknoloji temalı kamu politikalarının nihai performans sonucuna olan yansımaları hızlı değildir.

Bunula ilintili olarak gelişmiş ülkeler ile mukayese yapıldığında, Türkiye'deki teknopark çalışmalarının henüz inkişaf aşamasında olduğu tespiti de yapılabilir (Cansız, 2017). Ancak zaman da çok önemli bir parametredir ve dünyada her şey sürekli ilerleme eylemindedir. $\mathrm{Bu}$ sebeple belirli bir süre zarfından sonra etki analizi sonuçlarının değerlendirilerek teknoparkların katma değer oluşturarak ekonomik büyüme ve kalkınmaya olan etkilerini incelemek suretiyle genel anlamda ARGE ve teşvik politikalarının gözden geçirilmesi zaruri olacaktır. Böyle bir değerlendirmede, "mevcut koşullar olmasaydı aynı şirketler nasıl bir kümülatif etki yaratırlardı?" senaryosu üzerine çalışmak konunun analizinde önemli bir perspektif getirebilir. Ancak böyle bir simülasyon birçok parametreye dayalı varsayımlar ve tahminleri gerektirmektedir. Böyle bir çalışma hem objektif hem de subjektif verilere dayanacaktır.

Genel anlamda rahat bir çalışma ortamı ve etkileşim olanağı sağlayan organize platformlar olarak teknoparkların fayda yaratma potansiyelleri mevcuttur. Mesele etkinliğin nasıl arttırılacağıdır ve bu da teknoparkların en güçlü yönleri olan etkileşim gücünü en iyi seviyede kullanabilmeleri ile ilgilidir. Bu anlamda üniversite-sanayi işbirliğini arttırıcı etkin modeller, şirketlerin uluslararasılaşma kapasitelerini arttırıcı faaliyetler, yeni girişimcileri eğitmeye ve onları pazar ve finans kaynakları ile buluşturmaya yönelik çalışmalar faydalı ve gereklidir.

Özelde incelendiği vakit, firmaların sosyal ve iş erişim ağlarını büyütmek için yapılan faaliyetler çok önemlidir. Çünkü iş ağı ticaretin, pazarlamanın ve satışın ana unsurudur. Bu sebeple teknoparklarda düzenlenecek olan etkinlikler vasitası ile teknopark içerisindeki şirketlerin birbirini tanımaları onların birbirileri ile iş yapma imkânının önünü açacaktır. Benzer şekilde, teknoparkın önderliğinde yürütülecek küme faaliyetleri çerçevesinde bu küme firmaları hem birbirleriyle hem de yurtiçi ve yurtdışı iş-ortaklarıyla (partners) iş yapma ve iş ağlarını genişletme imkânı bulacaklardır. Bu faaliyetler firmaların bilgi kapasitelerini geliştirmeleri ve aynı zamanda da pazarlama ve satış potansiyellerini arttırmaları açısından son derece önemli faaliyetler olarak değerlendirilmelidir. Özünde bunların hepsi firmalar, kişiler ve kurumların iş birliklerini hem destekleyecek hem de arttıracak nitelikte çalışmalardır. Bu nedenle teknoparkların bu amaca yönelik proje, etkinlik ve faaliyetleri arttırmaları önemlidir. 
Öbür yandan üniversite-sanayi iş birliğinin geliştirilmesi için teknoparkların gerek kendi bünyelerindeki şirketleri ARGE faaliyetlerine destek olabilecek akademisyenlerle eşleştirmeleri, gerekse yapılarında bulunan teknoloji transfer ofisleri eli ile üniversitede bulunan potansiyel bilimsel çalışmaların, akademisyen-sanayi etkileşimi ile ticarileştirilmesine katkı sağlamaları, gerekse sanayide olan ihtiyaca dayanarak akademisanayi işbirliği ile çıktı sağlamalarına aracı olmaları genel anlamda katma değeri yaratacak çabalar olarak değerlendirilmektedir.

Aynı zamanda Türkiye'de şu ana kadar düşük seviyede gerçekleştirilen ARGE çıktılarının ticarileştirilmesinin arttırılması için teknoparkların finansman sağlama, finansman kaynaklarına erişimi için aracı olma ve firmaların projelerine yatırımcı ya da ortak bulma gibi faaliyet yürütmeleri de şirketlerin büyümelerine önemli faydalar sağlayacaktır.

Teknopark yönetimleri açısından başka önemli faaliyet şirketlerin zayıf yönlerini takviye edecek danışmanlık ve eğitim ile ilgili faaliyetler olacaktır. Bunlar firmaların bilgi ve kapasitelerinin arttırılmasına yarar sağlayacaktır.

Netice itibari ile nihai amaç, nitelikli hizmetleri daha iyi şekilde sağlayabilecek koşulları oluşturmak ve buna göre konuşlanmış teknopark yönetim ekiplerini oluşturmak olmalıdır. Aynı zamanda teknoparklar ARGE ekosistemi içerisinde koordine edici bir rol de üstlendikleri için bu kurumların karar verme mekanizmalarında üniversite, özel sektör ve kamu tecrübesinin pekiştiği kadroların görev yapmaları, başarıyı arttırıcı bir unsur olarak değerlendirilebilir. Benzer şekilde teknopark yönetici şirketinin de iş yönetimi, yurt içi ve dış pazarda iş geliştirme, pazarlama ve mühendislik gibi belli alanlarda uzmanlaşmış, özel sektör, kamu ve üniversiteler ile çalışma konusunda deneyimlenmiş, motivasyonu yüksek ve yetenekli insanlardan oluşması elzem olarak değerlendirilebilir.

Diğer taraftan burada belirtilmesi gereken çok önemli nokta konunun sadece teknopark yönetimlerinin ekosisteme sağladığı hizmetlerle değil aynı zamanda, devletin kamu politikaları ve planlama faaliyetlerinin yanı sıra üniversitelerin ve şirketlerin potansiyelleri ile doğrudan ilişkili olmasıdır. Netice itibari ile inkişafın temeli insan ve bilgi birikimidir. Bu da temel bilimler, sosyal bilimler ve mühendislik konusunda bilgi birikimine sahip bireyler ve kuruluşların mevcudiyetinin yanı sıra, üretim ve cihaz altyapısı, üretim imkânları, laboratuvar imkânları ve sermaye birikimi gibi unsurlara bağlıdır.

Eğitimin etkileri uzun vadede görülecektir. Ancak iyi bilim adamı, akademisyen ve öğretmen yetiştirmek ana amaçtır. Eğitimin daha başarılı olması için ise, çalışan ve çalışmayanın ayrıldığg ve öğrencilerin motive olduğu adil bir eğitim sisteminin idamesi şarttır. Bu suretle bilgileri özümsemiş, düşünebilen, özgür ve üretebilen bireylerin yetiştirilmesinin mümkün olabileceği değerlendirilebilir.

Aynı şekilde sanayileşmenin artması da bilimsel ve teknolojik gelişmeleri aynı ölçüde destekleyecek ve geliştirecek en önemli olgulardan birisidir. Onun için hem yurt içi hem de çok önemlisi yurt dışı iş birliklerinin gerekli olduğunu değerlendirmek gerekir. 
Sanayileşmenin güçlenmesi, birçok gelişmiş ülke örneklerinde de olduğu gibi hem yurt içi hem de yurtdış1 potansiyelinin entegrasyonu ile mümkündür.

$\mathrm{Bu}$ suretle, geniş perspektifli bir bakış açısıyla teknoparklar, tek başlarına bir unsur olmaktan ziyade ilköğretim kurumlarının, üniversitelerin, sanayi kuruluşlarının, diğer özel sektör ve kamu kuruluşlarının dâhil oldukları ve birbirileri ile en üst düzeyde etkileşimde bulundukları büyük bir eko sistemin parçalarıdır. Bu ekosistemin tüm unsurlarının kendi içlerindeki kapasitelerinin arttırılmasının yanı sıra hepsinin birbirileri ile etkin olarak bütünleşmesi de başarı için asıl ölçütlerdendir. Teknoparkların ise bu bütünleşme (integration) noktasında katalizör rolünü oynadıklarını söylemek yanlış olmaz. Bu yüzden bu görevlerini en etkin şekilde gerçekleştirebilecekleri en elverişli koşulların sağlanması gerekli ama tek başına yeterli olmayacaktır. Çünkü örneğin üniversite - sanayi işbirliğinin istenilen anlamda etkin çıktı yaratmaması, ya da bu çıktıların ekonomiye yeteri kadar dönüşememesinin ne kadarı uygulanan yöntemlerle, ne kadarı kamu politikaları ve planlama ile ve ne kadarı şirket ve kurumların potansiyel veya kapasitesi ile ilgilidir? Bu nedenlerden ötürü teknoparkların başarısı ve etkinliklerinin eko-sistemin tümü üzerinden değerlendirilmesi daha doğru olacaktır (Yereli, 2016). Bu bağlamda, ülke ekonomisindeki yoksulluğun yapısal nedenlerini gözeten bir kalkınma politikası ihtiyacını da vurgulamak gerekebilir, dolayısıyla, doğru teknolojiyi üreten-transfer eden-üretimde kullanan bir konuma gelmeden, "teknoloji yoksulluğu"nun aşılamayacağını öngören tartışmalar da bulunmaktadır (Tiryakioğlu, 2011).

Belirtilen çerçeve doğrultusunda örnek bir uygulama olarak, Gazi Teknopark ve Bilkent Cyberpark bünyesinde faaliyet gösteren 83 AR-GE firması örneklem grubunu oluşturmuştur. İncelenen dönem, 2010-2019 yıllarını kapsamıştır. Kalkınmaya konu olan değişkenlere ilişkin verilerin (istihdam, $A R-G E$, yurt içi ve yurt dışı satış ve ihracat) yıllara sair verilerinden yola çıkarak, 2020 ve 2021 yılları için ilgili değişkenlerin öngörü değerleri tespit edilmiştir. Böylece 10 yıl bareminde bahse konu değişkenlerin hangi yönde etki yaratacağı zaman serileri analizi ile araştırılmıştır. Buna göre teknoloji-yoğun bir ivme ile ülke orta-gelir ve orta-teknoloji tuzağından kurtulmak üzere sıçramadan söz ediliyorsa, Türkiye'nin makroekonomisine, teknoloji-yoğun ihracat bakımından yansıdı̆̆ı söylenemeyebilir. Yine de en azından, bu şirketlerin bir potansiyeli olduğu görülmektedir.

Bu çalışmada amaç “teknopark politikası” olup olmamasını tartışmak değildir fakat üniversite-sanayi işbirliğinde de sorun alanları varsa, onlar da gözden geçirilebilir. Yönetsel kapasite, ülkenin genel-geçer bir sorunu da olabilir. Nitekim bilim ve teknoloji politikası bağlamında, yeterince makro-ölçekli AR-GE ve teknoloji üretimi sağlanamadığı, ancak bir potansiyel ve sürekliliği işaret ettiği saptanabilir:

- Genel kapasite sorun-alanı irdelenmelidir; üniversite-sanayi-firma?,

- Bilim-inovasyon-teknoloji politikasının gözden geçirilmesi ihtiyaçtır,

- Teknopark ve mikro ölçekli firma kapasitesi sorunu giderilmelidir.

- Ürün/hizmet pazarlama-satış konusunda kapasite sorunu denilebilir mi, "kabiliyet midir"? Kaldı ki, böyle bir sorun da varsa incelenebilir. Tabi ki "iyi bir ürün” 
kendini satabilir, tanınır-aranır-talep görür (a good product sticks out and sells itself). Dolayısıyla, iyi kalitede bir ürün üretimi hedeflenmelidir.

\section{Kaynaklar}

Akçomak, İ.S. (2018), “Türkiye'nin Bilim, Teknoloji ve Yenilik Politikası Neleri Başaramadı?”, Sarkaç, <https://sarkac.org/2018/07/bilim-teknoloji-ve-yenilik/>, 25.11.2019.

Bilim ve Teknoloji Politikaları Araştırma Merkezi (2018), "Bilim, teknoloji ve yenilik politikası: Nereden nereye?", Blog, <http://tekpol.org/bilim-teknoloji-ve-yenilik-politikasi-neredennereye/>, 27.09.2018.

Bozeman, B. \& H. Rimes \& J. Youtie (2015), "The evolving state-of-the-art in technology transfer research: Revisiting the contingent effectiveness model", Research Policy, 44, 34-49.

Bozeman, B. (2000), "Technology Transfer and Public Policy: A Review of Research and Theory", Research Policy, 29(4-5), 627-655.

Cansız, M. (2017), 2023 'e Doğru Türkiye Teknoparkları, T.C. Kalkınma Bakanlığı, Sosyal Sektörler ve Koordinasyon Genel Müdürlügü.

Dağl1, İ. \& B.S. Oğuztürk (2018), "Planlı Dönemden Günümüze Türkiye'de Ulusal Bilim ve Teknoloji Politikalarının Değişimi”, SDÜ IIIBF Dergisi, 23(4), 1479-1503.

Güneş, S. \& T. Akın (2019), "Yüksek Teknoloji Urun İhracatı: Lider Ülkeler ve Türkiye Analizi”, Sosyoekonomi, 27(40), 11-29.

İlhan-Nas, T. \& F. Şahin (2018), "Doğrudan Yabancı Sermaye Yatırımı Kaynaklı Teknolojik Yayılımların Yerel Firmaların Uluslararasılaşma Faaliyetleri Üzerindeki Etkileri”, YOAD Yönetim ve Organizasyon Araştırmaları Dergisi, 3(1), 59-102.

Kaya, H. (2006), "Doğrudan Yurtdışı Yatırımlar Yoluyla Teknoloji Transferi ve Türkiye: Bir Literatür İncelemesi”, Uludağ Üniversitesi İIBF Dergisi, XXV(2), 85-102.

Konak, A. (2018), "Yüksek Teknoloji İçeren Urun İhracatının İhracat Hacmi ve Ekonomik Büyüme Üzerine Etkisi; Seçilmiş OECD Ülkeleri ve Türkiye Örneği”, Yönetim, Ekonomi, Edebiyat, İslami ve Politik Bilimler Dergisi, 3(2), 56-80.

Konings, J. (2001), "The effects of foreign direct investment on domestic firms: Evidence from firmlevel panel data in emerging economies", Economics of Transition and Institutional Change, 9(3), 619-633.

OECD (2011), ISIC Review. 3 Technology Intensity Definition, <https://www.oecd.org/sti/ind/48350231.pdf>, 22.05.2019.

Oğuztürk, B.S. (2004), “Türkiye'de Uygulanan Teknoloji Politikaları”, Doğu Anadolu Bölgesi Araştırmaları, 2(2), 100-105.

T.C. Sanayi ve Teknoloji Bakanlığı (2020), Teknoloji Geliştirme Bölgeleri, <https://atgm.sanayi.gov.tr/Handlers/DokumanGetHandler.ashx?dokumanId=25ae22040a4f-4d2e-aead-018dd12c8aac>, 23.01.2020.

Tiryakioğlu, M. (2011), “Teknoloji Transferi, Teknoloji Yoksulluğu mu?”, AÜ SBF Dergisi, 66(2), 169-199.

TÜBİTAK - ADANA - ÜSAM (2005), AB Üyesi Ülkelerde KOBI’lere Uygulanan Mesleki Eğitim ve Hizmetlerin Türk KOBI'lerine Uygulanması ve Yaygınlaştırılması Projesi, Proje N0:TR/05/A/F/EX1-1306.

USITTEM (N/A), TEKMER Nedir?, <http://usitem.cbu.edu.tr/db_images/site_402/file/tekmer.pdf>, 07.05.2019. 
World Bank (2019), World Development Indicators,

<https://databank.worldbank.org/data/reports.aspx?source=2\&country=TUR>, 23.05.2019.

Yaylal1, M. \& E.M. Doğan \& V.M. Yılmaz \& Z. Karaca (2015), “Türkiye'de Doğrudan Yabanc1 Yatırımlar ile Karbondioksit Emisyonu Arasındaki ilişkinin ARDL Yaklaşımı ile Araştırılması", The Journal of Operations Research, Statistics, Econometrics and Management Information Systems, 3(2), 107-112.

Yaylalı, M. \& Z. Karaca (2014), "Türkiye'de Araştırma Geliştirme Harcamaları ile Doğrudan Yabancı Yatırım İlişkisi: Sınır Testi Yaklaşımı”, ÇÜ İ̈BF Dergisi, 18(1), 77-87.

Yereli, A.B. (2008), “Kırgızistan'da Sürdürülebilir Bir Ekonomik Büyüme Açısından Teknoparkların Önemi”, Integration and Economic Development in Transition Economies, on the occasion of the 70th anniversary of Prof. Dr. TURAR KOYCHUEV, Proceedings, Kyrgyz-Turkish MANAS University, Department of Economics, KyrgyzTurkish MANAS University Publication: 106, Conference Series: 14, October 9-11, Bishkek-Kyrgyzstan, 81-87.

Yereli, A.B. (2016), “Öğretim Üyelerinin Teknoloji Geliştirme Bölgelerine Potansiyel Katkıları”, Manisa Celal Bayar Üniversitesi Ĕgitim Semineri, 8 Kasım, Manisa. 